\title{
Slavery and the new history of capitalism ${ }^{\dagger}$
}

\author{
Trevor Burnard ${ }^{1, \star}$ and Giorgio Riello ${ }^{2}$ \\ ${ }^{1}$ Wilberforce Institute, University of Hull, Hull, HU6 7RX, UK and ${ }^{2}$ Department of History and Civilization, European \\ University Institute, Via Bolognese 156, 50139 Florence, Italy \\ *Corresponding author. E-mails: T.G.Burnard@hull.ac.uk; giorgio.riello@eui.eu
}

\begin{abstract}
The new history of capitalism (NHC) places a great deal of emphasis on slavery as a crucial world institution. Slavery, it is alleged, arose out of, and underpinned, capitalist development. This article starts by showing the intellectual and scholarly foundations of some of the broad conclusions of the NHC. It proceeds by arguing that capitalist transformation must rely on a global framework of analysis. The article considers three critiques in relation to the NHC. First, the NHC overemphasizes the importance of coercion to economic growth in the eighteenth century. We argue that what has been called 'war capitalism' might be better served by an analysis in which the political economy of European states and empires, rather than coercion, is a key factor in the transformation of capitalism at a global scale. Second, in linking slavery to industrialization, the NHC proposes a misleading chronology. Cotton produced in large quantities in the United States came too late to cause an Industrial Revolution which, we argue, developed gradually from the latter half of the seventeenth century and which was well established by the 1790s, when cotton started to arrive from the American South. During early industrialization, sugar, not cotton, was the main plantation crop in the Americas. Third, the NHC is overly concentrated on production and especially on slave plantation economies. It underplays the 'power of consumption', where consumers came to purchase increasing amounts of plantation goods, including sugar, rice, indigo, tobacco, cotton, and coffee. To see slavery's role in fostering the preconditions of industrialization and the Great Divergence, we must tell a story about slavery's place in supporting the expansion of consumption, as well as a story about production
\end{abstract}

Keywords: capitalism; consumption; Great Divergence; Industrial Revolution; slavery

\section{Introduction}

The study of eighteenth- and nineteenth-century capitalism by mainstream historians has exploded in the last decade, celebrating what has been termed by its proponents the 'new history of capitalism' movement (NHC). ${ }^{1}$ The NHC has been trying to find its shared agenda. It has done so by stressing that a particular kind of rapacious capitalism emerged after the Columbian

\footnotetext{
${ }^{\dagger}$ We would like to thank the more than twenty colleagues who have read and commented on this article. We would also like to thank the anonymous referees for this journal for their stimulating and helpful comments.

'Interchange: the history of capitalism', Journal of American History, 101, 2, 2014, pp. 503-36; Jeffrey Sklansky, 'The elusive sovereign: new intellectual and social histories of capitalism', Modern Intellectual History, 9, 1, 2012, pp. 233-48; and Seth Rockman, 'What makes the history of capitalism newsworthy?', Journal of the Early Republic, 34, 3, 2014, pp. 439-68. For important examples of NHC history, see Jonathan Levy, Freaks of fortune: the emerging world of capitalism and risk in America, Cambridge, MA: Harvard University Press, 2012; Sven Beckert, Empire of cotton: a global history, New York: Knopf, 2014; Calvin Schermerhorn, The business of slavery and the rise of American capitalism, 1815-1860, New Haven, CT: Yale University Press, 2015; Daniel B. Rood, The reinvention of Atlantic slavery: technology, labor, race, and capitalism in the Greater Caribbean, New York: Oxford University Press, 2017; Jeffrey Sklansky, Sovereign of the market: the money question in early America, Chicago, IL: University of Chicago Press, 2017; and Caitlin Rosenthal, Accounting for slavery: masters and management, Cambridge, MA: Harvard University Press, 2018.
}

(c) Cambridge University Press 2020. This is an Open Access article, distributed under the terms of the Creative Commons Attribution licence (http://creativecommons.org/licenses/by/4.0/), which permits unrestricted re-use, distribution, and reproduction in any medium, provided the original work is properly cited. 
exchange of the late fifteenth and sixteenth centuries, in patterns of colonial conquest, expropriation of native American lands, and abusive labour relations, leading to the invention of a pernicious form of enslavement, based on the racial debasement of African people transported to New World plantations. Sven Beckert, in the most important book to emerge from the NHC movement to date, refers to this by the neologism 'war capitalism'. In this view, the exploitation of the New World led to the enrichment of Europe, abetted and intensified European imperialism (which in turn accentuated further ravishing of indigenous lands and people), and culminated in the impoverishment of non-European worlds - the rise of the West being both deliberate and dreadful. ${ }^{2}$

In this article, we concentrate on one area of interest for NHC historians. Eric Hilt has conveniently grouped the works of the NHC into three broad areas, one of which is slavery and capitalism. The other two are finance, risk, and insurance; and conservative economic doctrines. As Hilt wryly observes, these areas present a 'critical account of the development of the American economy' from the original sin of colonization and slavery, through nineteenthcentury crony capitalism, to late twentieth-century backlashes against the welfare state and the development of economic doctrines friendly to business interests and aggressive free market philosophies. ${ }^{3}$ It is important to note, also, that the NHC is a movement that comes primarily out of the historiography of the nineteenth-century USA and is heavily America-centric. Our criticisms in this article are broader than customary in critiques of the NHC. We concentrate on two areas: the extension of nineteenth-century US history into the history of the eighteenth-century Atlantic world, and the NHC approach to global history, which is more intended to make the practice of US history international than one that is truly global. ${ }^{4}$

The NHC argues that slavery was a crucial world institution. As Mary O'Sullivan notes, 'slavery features so prominently in the recent history of capitalism, especially in its interpretation of US capitalism, that Sven Beckert and Seth Rockman claim it has fostered a fundamental recasting of the country's history of economic development until the Civil War as "slavery's capitalism"'. ${ }^{5}$ While a century-long tradition of scholarship on capitalism has emphasized its varieties, ranging from commercial capitalism to agrarian industrial and financial capitalism, Beckert's 'war capitalism' is underpinned by slavery. ${ }^{6}$

The emphasis on the active role of slavery in promoting capitalist development has opened a debate that had seemed closed. By the early 2000s, Barbara Solow reflected a strong orthodoxy among economic historians about the importance of slavery in European capitalism. She declared that 'slavery did not cause the Industrial Revolution but played an active role in its pattern and timing. ${ }^{7}$ David Eltis and Stanley Engerman, by contrast, reflected that consensus by concluding that slavery and the slave trade were of marginal importance in the main currents of economic growth, even in Britain, where the argument for the transformative effect of slavery on industrial

\footnotetext{
${ }^{2}$ Beckert, Empire of cotton, pp. 29-82.

${ }^{3}$ Eric Hilt, 'Economic history, historical analysis, and the "new history of capitalism", Journal of Economic History, 77, 2, 2017, p. 513.

${ }^{4}$ For general work, see Michael Zakim and Gary Kornblith, eds., Capitalism takes command: the social transformation of nineteenth-century America, Chicago, IL: University of Chicago Press, 2012; and Sven Beckert and Christine Desan, eds., American capitalism: new histories, New York: Columbia University Press, 2018. For a criticism of Beckert's work from the vantage point of twentieth-century Egypt, see Aaron G. Jakes and Ahmad Shokr, 'Finding value in Empire of Cotton', Critical Historical Studies, 4, 1, 2017, pp. 107-36. For capitalism in colonial America, see Emma Hart, Trading spaces: the colonial marketplace and the foundations of American capitalism, Chicago, IL: University of Chicago Press, 2019.

${ }^{5}$ Mary O'Sullivan, 'The intelligent woman's guide to capitalism', Enterprise and Society, 19, 4, 2018, p. 762.

${ }^{6}$ For an earlier debate over the origins of capitalism, involving competing theories by Fernand Braudel, Immanuel Wallerstein, Maurice Dobbs, and Robert Brenner, see Trevor Aston and C. H. E. Philpin, eds., The Brenner debate: class structure and economic development in pre-industrial Europe, Cambridge: Cambridge University Press, 1985.

${ }^{7}$ Barbara Solow, 'Caribbean slavery and the Industrial Revolution', in Barbara Solow and Stanley L. Engerman, eds., British capitalism and Caribbean slavery, Cambridge: Cambridge University Press, 1987, p. 72.
} 
development had always been most influential, thanks to the work of Eric Williams on capitalism and slavery, written in $1944 .^{8}$

Williams' book advanced a breath-taking number of assertions about the role of slavery in British life in the eighteenth and nineteenth centuries. Four of his arguments are critical to the NHC project: that slavery was central to the Industrial Revolution; that slave wealth was important to the history of eighteenth-century Britain; that the West Indian slave economy went into decline from 1783; and that West Indian slave-owners moved from being a progressive force within mercantilism to being a reactionary force within industrial capitalism. ${ }^{9}$ But none of these contentions fit within much of what the NHC does, as the NHC project is very much about the origins of American rather than British, or even world, capitalism. What is important to stress is that Williams' focus of attention was Britain before the beginnings of abolitionism, and after the American Revolution (though he had important things to say about the end of tariff protection for products from the West Indies in the 1840s and the advent of free trade). His work was rooted deeply in mid-twentieth-century understandings of British imperialism, and of asserting a materialist interpretation of history, derived from the discipline of economic history. He believed that no democratically inclined government can ever act except in advancing the material interests of its people. Thus, every British action, including abolitionism, had to be about improving Britain's material position. That focus on relentless materialism drove every part of his set of theses on British involvement with slavery. His contemporary defenders, however, use Williams for historical perspectives he never considered. Williams devotes very little attention in his book either to America or to cotton - he has little interest in trying to explain how American capitalism was connected to America's long involvement in slavery. Nor is he especially interested in Africa and the question that Joseph Inikori is most concerned about, which is that the Industrial Revolution owed much more to Africa and Africans than previously thought. ${ }^{10}$

Three-quarters of a century after Williams, the NHC has built upon the relationship between slavery and capitalism at a time in which global history provides a new framework of analysis for both concepts. ${ }^{11}$ One NHC achievement is that it reinserts politics and power into Kenneth Pomeranz's influential thesis on the Great Divergence, in which he posited that lands from which the indigenous population had been removed in the Americas provided 'ghost acres' that ended Britain's need to maximize food production. He therefore concluded that plantations helped to make the West decisively richer than Asia from the end of the eighteenth century. ${ }^{12}$ A second important element borrowed from the Great Divergence debate is the linking of capitalism and industrialization. Beckert, for instance, directly connects war capitalism and the industrial capitalism of the nineteenth century. Linking the two is the institution of slavery, which in the NHC becomes not a means but an end to capitalism. That argument connects the NHC to the work of Williams' best modern-day defender, Inikori, who provides important

${ }^{8}$ David Eltis and Stanley L. Engerman, 'The importance of slavery and the slave trade to industrializing Britain', Journal of Economic History, 60, 1, 2000, p. 138; Eric Williams, Capitalism and slavery, Chapel Hill, NC: University of North Carolina Press, 1944.

${ }^{9}$ See Catherine Hall, Nicholas Draper, and Keith McClelland, eds., Emancipation and the making of the British imperial world, Manchester: Manchester University Press, 2014.

${ }^{10}$ Joseph E. Inikori, Africans and the Industrial Revolution in England: a study in international trade and economic development, Cambridge: Cambridge University Press, 2002.

${ }^{11}$ Robert C. Allen, Global economic history: a very short introduction, Oxford: Oxford University Press, 2011; and Francesca Trivellato, 'The organization of trade in Europe and Asia, 1400-1800', in Jerry H. Bentley et al., eds., The Cambridge world history, volume 6: the construction of a global world, 1400-1800 C.E. Pt. 2: patterns of change, Cambridge: Cambridge University Press, 2015, pp. 160-89.

${ }^{12}$ The link is implied rather than explicit. The NHC largely ignores debates over divergence and thus sidelines the role of Asia in global processes of economic development. 
scholarship allowing the NHC to expand what is mainly an American story into one that is Atlantic and African. ${ }^{13}$

Did slavery really provide the material preconditions and intellectual underpinnings for merchant capitalism to morph into industrial capitalism in western Europe? The NHC takes Pomeranz's invitation to place more emphasis on the role of the Americas in promoting the industrialization that underpinned the Great Divergence. Yet, the NHC methodological orientation - seldom expressed directly - is mostly derived from Wallerstein's world-systems theory, not from debates on the Great Divergence. ${ }^{14}$ It stresses the transformative role of American raw cotton in British industrialization after the invention of the cotton gin, but provides a narrow view of economic change, in which slavery and the plantation economy are taken as the sole motor of early modern global economic change.

Our contribution is divided into three parts. We start with a critical analysis of the origins and intentions of the NHC. Next, we analyse the relationship between capitalism and slavery, and argue that capitalist transformation must rely on multi-factor explanations, in which slavery plays only one part. Finally, we make specific criticisms of the current debate around capitalism and slavery as interpreted by the NHC, casting doubt upon the importance of coercion within slavery to economic growth and the origin of modern capitalism; we query the chronology adopted by the NHC in which cotton rather than sugar is the crop that does the work of transforming through slavery forms of capitalism; and we argue that the NHC's stress on production, and on the 'power of coercion' in the production of industrial outputs, underplays the 'power of consumption', whereby consumers came to purchase increasing amounts of plantation goods, including sugar, rice, indigo, tobacco, cotton, and coffee.

\section{The new history of capitalism: intellectual foundations and criticisms}

The historiographical origins of the NHC lie in the intersection of social, economic, and intellectual history that arose in the work on the 'making of the working class' in the 1960s and 1970s. ${ }^{15}$ The NHC has critically revised the analytical categories that organized previous work, leading to a subtle shift in the storyline from proletarianization to commodification. ${ }^{16}$ It also resists debates over origins and transitions from earlier forms of economic organization to industrial capitalism, a movement in which traditionally nineteenth-century slavery is presented as both pre-capitalist and an anachronism. ${ }^{17}$ Instead, NHC historians have argued for the centrality of capitalist notions of property, price, and profit within slavery as much as within wage labour. Thus, the origins of the NHC lie in different directions from the ideas of most economic historians, who conclude that slavery was not that central in developing British industrialization. ${ }^{18}$

\footnotetext{
${ }^{13}$ Inikori, Africans and the Industrial Revolution. See also 'Roundtable: reviews of Joseph Inikori's Africans and the Industrial Revolution in England with a response by Joseph Inikori', International Maritime Review, 15, 2003 , pp. $279-361$.

${ }^{14}$ Beckert refers to world-systems theory only in passing but is heavily influenced by its axioms. See Immanuel Wallerstein, The modern world system: capitalist agriculture and the origins of the European world-economy in the sixteenth century, New York: Academic Press, 1976.

${ }^{15}$ Tony Judt, 'A clown in regal purple: social history and the historians', History Workshop Journal, 7, 1979, pp. 66-94; Elizabeth Fox-Genovese and Eugene Genovese, 'The political crisis of social history: a Marxian perspective', Journal of Social History, 10, 2, 1976, pp. 205-20.

${ }^{16}$ Karl Polanyi, The great transformation: the political and economic origins of our time, New York: Amereon House, 1944; Eric Hobsbawm, The age of revolution: Europe, 1789-1848, London: Weidenfeld \& Nicolson, 1962.

${ }^{17}$ Walter Johnson, 'The pedestal and the veil: rethinking the capitalism/slavery question', Journal of the Early Republic, 24, 2, 2004, p. 304.

${ }^{18}$ These origins may explain the downplaying of work that preceded NHC. The lack of recognition of past endeavours has riled some economic historians. Peter Coclanis, 'Slavery, capitalism, and the problem of misprision', Journal of American Studies, 52, 3, 2018, pp. 8-9.
} 
The historiography upon which the NHC has set its sights is a labour history in which capitalism is presented as a 'great transformation' from societies with markets to market societies, in Karl Polanyi's formulation, or 'dual revolutions' in political and economic life, as Eric Hobsbawm argued. The NHC does not believe in such teleological formulations. It sees capitalism as something that does not need to be defined, except empirically, and as being more a climate of thought and social practice than a social order, with no obvious sequential processes. The rhythm of 'capitalist temporality', in William Sewell's words, becomes 'hypereventful but monotonously repetitive', a constant feature of human life, which should be studied without reference to searches for evolution and revolution. ${ }^{19}$ It also renders obsolescent, as Jeffrey Sklansky comments, previous formulations that delimited capitalism's territorial or temporal reach. ${ }^{20}$ That allows for a new subject to replace the standard white European worker of social history.

To an extent, the NHC, in its reluctance to engage in debates about the definition of capitalism, accords with Fernand Braudel's well-known argument that capitalism did not move into its mature stage only in the world of nineteenth-century industrialization. Braudel believed that there was a unity to capitalism from its start in thirteenth-century Italy to the present day. That unity was based on a fundamental feature of capitalist societies, in that it was characterized by 'its unlimited flexibility, its capacity for change and adaptation'. ${ }^{21}$ The NHC makes an important point that capitalist structures were transformed as the result of the Columbian encounter and the violence of European colonization, thus showing that Braudel was right about the adaptability of the system to dramatic change. Emphasizing adaptation and flexibility may justify the reluctance of the NHC to engage in definitional debate. ${ }^{22}$ If there is a methodological ethos that unites the proponents of the NHC, it is an opposition to neoclassical views of the economy, and a pride that they do not write Marxist history. They are reluctant to see economic life as being based on natural laws, and instead insist that economic affairs are derived from political construction. ${ }^{23}$

What fascinates the NHC is less how the working class was made at the start of industrialization, and more how capitalism relied on the labour of people in various forms of unfreedom. That perspective makes it unsurprising that nineteenth-century slavery becomes paradigmatic. People in the borderlands between slavery and freedom - paupers, prisoners, 'coolies', peons, sharecroppers, and the enslaved - were connected by what Seth Rockman calls a 'common commodification', in which their terms of labour 'came to be dictated by the limitless pursuit of monetary profit rather than the limited demand for material goods. ${ }^{24}$ Slavery is so central to capitalism in the NHC script that without it the entire history of the western hemisphere would be different, especially in Britain and the US, where, it is argued, virtually no aspect of the economy can be explained without reference to slavery's baleful influence.

\footnotetext{
${ }^{19}$ William H. Sewell, 'The temporalities of capitalism', Socio-Economic Review, 6, 3, 2008, p. 527.

${ }^{20}$ Jeffrey P. Sklansky, 'The elusive sovereign: new intellectual and social histories of capitalism', Modern Intellectual History, 9, 1, 2012, pp. 233-48.

${ }^{21}$ Fernand Braudel, Civilization and capitalism, 15th-18th century, vol. 2: The wheels of commerce, New York: Harper Row, 1982, p. 433. On wider debates, see Jürgen Kocka, Capitalism: a short history, Princeton, NJ: Princeton University Press, 2017; and Larry Neal and Jeffrey G. Williamson, eds., The Cambridge history of capitalism, 2 vols., Cambridge: Cambridge University Press, 2015.

${ }^{22}$ As Philip Scranton argues, what historians of capitalism ought to be doing is to 'locate capitalism's actors and stakeholders and follow them and their rivals across space and time', in order to 'uncover situated supporting and limited laws, cultural dispositions, customs and practices and assess their salience to organizations and outcomes'. Philip Scranton, 'The history of capitalism and eclipse of optimism', Modern American History, 1, 1, 2018, pp. 109-10.

${ }^{23} \mathrm{Nan}$ Enstad, "The "sonorous summons" of the new history of capitalism, or, what are we talking about when we talk about economy', Modern American History, 2, 1, 2019, p. 84.

${ }^{24}$ Seth Rockman, Scraping by: wage labor, slavery, and survival in early Baltimore, Baltimore, MD: Johns Hopkins University Press, 2009, p. 11.
} 
There has been no lack of critical voices about this scholarship. ${ }^{25}$ Social historians have criticized the NHC for ignoring, or even failing to comprehend, previous debates, often influenced by investigations into stadial history in the eighteenth century, and into Marxism, in which defining the terms of capitalism is crucial. In the readings that the NHC makes of capitalism, it appears as a realm with no rules, only containing subjects of the seemingly authoritarian edicts of the market. Structures of power and social struggle, it is noted, are often relegated to the sidelines. $^{26}$

Economic historians have been critical of the NHC as overtly judgemental and ahistorical. Gavin Wright, the doyen of economic historians of slavery in the nineteenth-century American South, for example, welcomes this 'new interest in economic aspects of slavery on the part of younger scholars' as a 'good thing, an opportunity for cross-disciplinary learning and cooperation'. But he criticizes arguments made by NHC historians that 'identif[y] slavery as the primary force during key innovations in entrepreneurship, finance, accounting, management, and political economy' as being 'bluster and bombast'. He concludes that it is unfortunate that historians pursuing original inquiries on slavery-related topics have been persuaded to present their work as apparent disciples of a militant insurgency' and that 'there is no intellectual gain in recasting this historical project as a team sport'. ${ }^{27}$ Alan Olmstead and Paul Rhode are even more critical. They admit that there is something worthwhile in the NHC's insistence that capitalism in the US has a 'barbarous' side to it, but observe that 'much that has been true in the NHC story has long been commonplace', and that it 'makes spectacular and unsupported claims, relies on faulty reasoning, and introduces many factual inaccuracies' ${ }^{28}$

The NHC has also attracted criticisms from gender historians. Nan Enstad notes that, in the major edited collections, and in the field-defining statements, 'we see that women and gender history are poorly represented indeed', while Mary O'Sullivan comments on just how few female authors there are in discussions of capitalism. O'Sullivan explains that 'men continue to exercise a virtual monopoly in writing guides to capitalism, with some of them explicitly targeting these guides at their own daughters and granddaughters'. She concludes that 'the extent to which opining on capitalism remains a man's world is as striking as it is disgraceful'. ${ }^{29}$ Amy Dru Stanley bluntly declares that 'the emergent grand narrative of the NHC is blind to feminism, gender and sex difference', while Ellen Hartigan-O'Connor suggests that women exist as minor characters in the history of capitalism and that the consideration of women in the economy as principal actors has become worse with the advent of the NHC. ${ }^{30}$

What is significant is that the elision of gender leads to misconceptualizations, and to the reiteration of old and discarded narratives, in which men are active and women are passive. It is notable, for example, that the illustrations accompanying Beckert's Empire of cotton are overwhelmingly of masculine figures doing masculine actions, such as brokering sales of cotton. Gender in the NHC relates to the study of the 'other', with little appreciation that 'economy' is itself an inherently gendered category. ${ }^{31}$ And sometimes the manner in which the topics of

\footnotetext{
${ }^{25}$ Alan L. Olmstead and Paul W. Rhode, 'Cotton, slavery, and the new history of capitalism', Explorations in Economic History, 67, 1, 2018, pp. 1-17; Hilt, 'Economic history'.

${ }^{26}$ Scott Reynolds Nelson, 'Who put their capitalism in my slavery?', Journal of the Civil War Era, 5, 2, 2015, pp. $289-310$. For an excellent critique of NHC, see Nicolas Barreyre and Alexia Blin, 'À la redécouverte du capitalisme américain', Revue d'histoire du XIXe siècle, 54, 1, 2017, pp. 135-48.

${ }^{27}$ Gavin Wright, review of Sven Beckert and Seth Rockman, eds., Slavery's capitalism: a new history of American economic development, Philadelphia, PA: University of Pennsylvania Press, 2016, EH.Net, https://eh.net/book_reviews/slaveryscapitalism-a-new-history-of-american-economic-development/ (consulted 12 July 2019).

${ }^{28}$ Olmstead and Rhode, 'Cotton', pp. 2 and 15.

${ }^{29}$ Enstad, 'Sonorous summons', p. 90; O’Sullivan, 'Intelligent woman's guide', p. 753.

${ }^{30}$ Amy Dru Stanley, 'Histories of capitalism and sex difference', Journal of the Early Republic, 36, 2, 2016, p. 343; Ellen Hartigan-O'Connor, 'The personal is political economy', Journal of the Early Republic, 36, 2, 2016, p. 337.

${ }^{31}$ Hartigan-O'Connor, 'Personal is political economy', pp. 349-50; Enstad, 'Sonorous summons', p. 91.
} 
gender history are treated can have a condescending tone. Peter Hudson chides Edward Baptist for using language about sexual violence that, while dependent upon black feminist scholarship, is 'frivolous', and 'which in its conversational, intimate tone ... undermine[s] the gravity of sexual violence'. He concludes that Baptist's 'discussions of racial and sexual violence ... come off as alarmingly light; his repetition of the trope of a "one-eyed man" betrays a schoolboy puerility while making an extended joke about raping black women'. ${ }^{32}$

The NHC's anaemic gender visions have consequences. Focusing on men and on production in the relation between slavery and capitalism underplays the active role that women in Britain played as consumers of slave-produced goods, and in the significance of enslaved reproduction in fashioning the worldwide expansion of the cotton trade. ${ }^{33}$ It also contributes to a principal weakness in the subject matter covered in the NHC: its lack of appreciation for and interest in abolitionism, a transatlantic movement in which women featured prominently, both as activists and as objects of agitation. The physical and sexual mistreatment and exploitation of enslaved women was a fundamental theme within abolitionist discourse, and one of the most successful means whereby opponents of slavery showed that the institution was essentially immoral, no matter how much it contributed economically to imperial and American coffers.

All that Beckert and Rothman can say about abolitionism in their introduction to a collection of essays entitled, Slavery's capitalism, is that 'whereas an older scholarship saw capitalism and abolitionism as concurrent and mutually reinforcing, newer work highlights the material and ideological convergence of capitalism and slavery in the dynamic emergence of long-distance markets for financial securities, agricultural commodities, and labor power'. In other words, abolitionism came entirely out of debates on the nature of capitalism and after the Industrial Revolution had been underwritten, as Williams argued, by the transatlantic slave trade. There is no gesture towards the enormous literature on abolition that stresses the religious motivations held by anti-slavery proponents. ${ }^{34}$

A final issue that has attracted attention to the NHC is that its advocates relentlessly trumpet that their findings are 'new'. Scholars working on capitalism and slavery in all of the above-mentioned fields observe that their efforts in this area are often not evaluated, and at times not even acknowledged. ${ }^{35}$ That nineteenth-century American planters were 'as rational, entrepreneurial, and grasping as any factory titan' is not a new finding. ${ }^{36}$ Similarly, economic historians are right to point out that asserting the evil nature of planters and their inherently capitalist orientations has been a staple of work in economic history on American slavery for the last sixty years. ${ }^{37}$ In addition, the arguments made by the NHC that it has advanced a new understanding of the Industrial Revolution are historiographically limited by their assumption that little work on this topic has been done between the pioneering work of Eric Williams in 1944 and today.

By overplaying some of its arguments, the NHC falls short on clarity. As Barreyre and Blin note, it fosters an all-encompassing vision of capitalism that is consistent with all forms of market economy, thus blurring our knowledge of the destructive character of different forms of capitalism, and especially its temporal and spatial aspects. ${ }^{38}$

\footnotetext{
${ }^{32}$ Peter James Hudson, 'The racist dawn of capitalism: unearthing the economy of bondage', Boston Review, 14 March 2016, http://bostonreview.net/books-ideas/peter-james-hudson-slavery-capitalism (consulted 12 July 2019).

${ }^{33}$ American slavery was based upon a naturally growing enslaved population, which meant that they did not have to rely on new additions of labour from the Atlantic slave trade. The opposite was true in the Caribbean.

${ }^{34}$ Sven Beckert and Seth Rockman, 'Introduction: slavery's capitalism', in Beckert and Rockman, Slavery's capitalism, pp. 4 and 10 (quotation from p. 10).

${ }^{35}$ Coclanis, 'Slavery', pp. 1-9.

${ }^{36}$ Kenneth Lipartito, 'Reassembling the economic: new departures in historical materialism', American Historical Review, 121, 1, 2016, pp. 115-16.

${ }^{37}$ Olmstead and Rhode, 'Cotton'.

${ }^{38}$ Barreyre and Blin, 'À la redécouverte du capitalisme américain'.
} 


\section{Slavery and capitalism revisited}

The NHC's concern with slavery is as much political as it is academic. Peter Coclanis observes that it was the Great Recession of 2008 that got historians thinking once more about the material conditions of past lives. ${ }^{39}$ In their introduction to Slavery's capitalism, Seth Rockman and Sven Beckert observe that 'A scholarly revolution over the past two decades, which brought mainstream historical accounts into line with long-standing positions in Africana and Black Studies, has recognized slavery as the foundational American institution, organizing the nation's politics, legal structures, and cultural practices. ${ }^{40}$ The new attention is welcome. Yet their claims are sweeping, polemical, and rooted in present-day politics, seeking to wrest the study of capitalism from economic historians, who, they argue, 'naturalize' the subject, and thus minimize its negative consequences, especially for poorer people. ${ }^{41}$

The new interest in slavery is probably more an evolution of historiographical attention than a 'scholarly revolution', as scholars have never stopped investigating the economics of slavery and its relation to economic growth. Gavin Wright argues that slavery played a part in increasing economic growth, but only a small part in the origins of American industrialization, and a limited role compared to other factors in industrialization in general. ${ }^{42}$ Slavery was important everywhere in nineteenth-century America. So, too, eighteenth-century Britain was imbricated in slavery in many ways. Until recently, slave ownership was virtually invisible in British history: it was something that happened elsewhere, although it did so in places controlled and shaped by British imperialism. Britain's involvement with slavery was that it stopped it, by abolishing first the slave trade in 1807, and then slavery itself in 1834. The latter event was accompanied by an enormous compensation of $£ 20$ million to slave-owners, many resident in Britain, a sum equivalent to one-fifth of government expenditure in $1834 .{ }^{43}$ But even well after emancipation in the British empire had occurred, former slave-owners played an important part in the shaping of modern British society, as agents and subjects of a new world in which slavery had gone. To take one example, the great Victorian prime minister William Ewart Gladstone derived his wealth from the immense colonial holdings of his father, Sir John Gladstone, which included thousands of enslaved people. ${ }^{44}$

Thus, the efforts of the NHC to restore historical attention to the role of slavery in the British and American economies in the eighteenth and nineteenth centuries is welcome. The NHC agrees with Pomeranz that slavery and plantations were key factors in the transformation of the early modern world economy. But it differs from Pomeranz on two substantial points. First, the NHC sees slavery as more important than industrialization in the shaping of modern capitalism. ${ }^{45}$ Second, and as a corollary of the previous point, advocates of NHC believe that Williams was not only right in seeing slavery as central to the development of capitalism, but also that his insights understate the importance of slavery in the making of modern world. ${ }^{46}$

\footnotetext{
${ }^{39}$ Coclanis, 'Slavery', p. 2.

${ }^{40}$ Beckert and Rockman, 'Introduction', p. 1.

${ }^{41}$ Louis Hyman, 'Why write the history of capitalism?', Symposium Magazine, 8 July 2013, http://www.symposiummagazine.com/why-write-the-history-of-capitalism-louis-hyman (consulted 12 July 2019).

${ }^{42}$ Gavin Wright, Slavery and American economic development, Baton Rouge, LA: Louisiana State University, 2006.

${ }^{43}$ Nicholas Draper, The price of emancipation: slave-ownership, compensation and British slavery at the end of slavery, Cambridge: Cambridge University Press, 2010.

${ }^{44}$ Catherine Hall et al., eds., Legacies of British slave-ownership: colonial slavery and the formation of Victorian Britain, Cambridge: Cambridge University Press, 2016; Madge Dresser et al., Slavery and the British country house, Swindon: English Heritage, 2013; S. D. Smith, Slavery, family and gentry capitalism in the British Atlantic: the world of the Lascelles, 1648-1834, Cambridge: Cambridge University Press, 2006; Trevor Burnard and Kit Candlin, 'Sir John Gladstone and the debate over amelioration in the British West Indies in the 1820s', Journal of British Studies, 57, 4, 2018, pp. 760-82.

${ }^{45}$ James Oakes, 'Capitalism and slavery and the Civil War', International Labor and Working-Class History, 89, 2016, pp. 195-220; Hilt, 'Economic history'; 'Interchange: the history of capitalism'.

${ }^{46}$ Sven Beckert, 'Slavery and capitalism', Chronicle of Higher Education, 12 December 2014.
} 
The historiographical pendulum is swinging away from a view that Williams was thoughtprovoking more than persuasive, which held sway among scholars in the 1980s and 1990s, to a movement among economic historians that accepts a modified version of the Williams thesis. Key works in this re-evaluation are Pomeranz's The Great Divergence and Inikori's Africans and the Industrial Revolution in England. Pomeranz saw the Atlantic slave economy as crucial to economic growth in Britain, with its ability to add 'phantom land' in the colonies to Britain's agricultural capacity, so that, with coal, the British could break free from Malthusian constraints and explode economically, and Britain and western Europe could overtake China in wealth and power. ${ }^{47}$ Inikori reasserted Williams' thesis about the pervasive influence of Africans, slavery, and the slave trade on economic growth in Britain over the long term, arguing that Atlantic slavery was closely associated with the commercialization of agriculture, and that both were preludes to industrialization in the late eighteenth century. He attempted to change the focus of discussion away from the causal relations between British industrial capitalism and the abolition of the slave trade and slavery, and towards an overall assessment of the role of Africans in Africa, even more than those in the Caribbean, in the course of the Industrial Revolution. ${ }^{48}$

The NHC's origins in debates over nineteenth-century American slavery have, as Mary O'Sullivan notes, meant that it has not engaged with some important themes, notably rates of profit over time and space in the eighteenth-century British West Indies, inspired by the rich historical literature coming out of debates over the Williams thesis. As O'Sullivan argues, the NHC has been more concerned about commodification than about capital's relationship to profit, the latter being what she considers axiomatic to any consideration of capitalism. That emphasis on commodification has yielded major insights, as the work of Daina Berry and Caitlin Rosenthal have shown in evaluating the economic and cultural implications of attaching prices to humans. ${ }^{49}$

By contrast, historians of slavery and capitalism in the Caribbean have been fascinated by rates of profit, if only to confirm or refute Williams' contentions. J. R. Ward, David Beck Ryden, Selwyn H. H. Carrington, and Ahmed Reid have all made significant contributions to the history of plantation profits, which show that British West Indian plantations were profitable up until the 1820s, with a blip during the American Revolution. ${ }^{50}$ Historians of the French and British Caribbean have been very interested in how tropical crops were produced, unlike most historians - Alan Olmstead and Paul Rhode excepted - working on antebellum Southern cotton production. ${ }^{51}$ Working out profit margins and returns on capital is vital for understanding slavery's connection to capitalism, because profit is 'the engine of the capitalist economy', and the dominant source of capitalist investment and accumulation, and of the enrichment of the business bourgeoisie. ${ }^{52}$ Of course, calculating rates of profit is very difficult. Early modern and eighteenth-century historians have to reconstruct such rates from

\footnotetext{
${ }^{47}$ Kenneth Pomeranz, The Great Divergence: China, Europe, and the making of the modern world economy, Princeton, NJ: Princeton University Press, 2001.

${ }^{48}$ Inikori, Africans and the Industrial Revolution.

${ }^{49} \mathrm{O}$ 'Sullivan, 'Intelligent woman's guide', pp. 775-77; Daina Ramey Berry, The price for their pound of flesh: the value of the enslaved from womb to grave in the building of a nation, Boston, MA: Beacon, 2017; Rosenthal, Accounting for slavery.

${ }^{50}$ David Beck Ryden, 'Does decline make sense? The West Indian economy and the abolition of the British slave trade', Journal of Interdisciplinary History, 31, 3, 2001, pp. 347-74; Selwyn H. H. Carrington, 'Management of sugar estates in the British West Indies at the end of the eighteenth century', Journal of Caribbean History, 33, 1999, pp. 30-43; Ahmed Reid, 'Sugar, slavery and productivity in Jamaica, 1750-1807', Slavery \& Abolition, 37, 2, 2016, pp. 159-82; J. R. Ward, 'The profitability of sugar planting in the British West Indies, 1650-1834', Economic History Review, 31, 2, 1978, pp. 197-213.

${ }^{51}$ Alan Olmstead and Paul Rhode, 'Biological innovation and productivity growth in the antebellum cotton economy', Journal of Economic History, 61, 4, 2008, pp. 1123-71.

${ }^{52}$ Jean Bouvier, François Furet, and Marcel Gillet, Le mouvement du profit en France au 19e siècle, Paris: Mouton, 1965 , p. 9.
} 
data that were not created in order to measure profits, and thus have to rely upon heroic assumptions that make establishing rates of profit merely guesses. ${ }^{53}$

Economic historians such as Nuala Zahedieh and Pat Hudson largely accepted the thrust of Inikori's argument, and have added their own arguments to the mix. Zahedieh insists that the growth of Atlantic trade was essential for the late seventeenth-century development of the copper industry, as well as for sustaining industries such as shipbuilding. Moreover, it was central in encouraging financial innovations. Zahedieh argues that the endogenous responses to the market opportunities created by imperial expansion led to advances in London's commercial leadership in Europe, better transport networks, improvements in early manufacturing capacity, and an increase in 'useful knowledge', as people acquired mathematical and mechanical skills necessary for complicated trade. She concludes that the highly successful plantation trade outperformed other sectors in the late seventeenth century. It also stimulated 'adaptive innovations which took the country to a new plateau of possibilities from which the Industrial Revolution was not only possible but increasingly likely'. ${ }^{54}$ Hudson concentrates on the importance of the slave trade and slavery in fostering institutional change, not least some of the changes which accompanied the financial revolutions of the late seventeenth century. She argues that, while conceivably such institutional innovations might have come from other origins than slavery, in fact slavery helped finance new industries, such as copper production, and new forms of financial instruments to manage new levels of debt and credit. ${ }^{55}$

Williams was correct to argue for the strong and growing effect of slavery and the slave trade on British life in the late seventeenth and early eighteenth centuries. Recent reinterpretations of the Industrial Revolution emphasize that it was an evolutionary process that lasted over the whole of the eighteenth century. ${ }^{56}$ Overseas trade was crucial to this process. As Zahedieh argues,

England's extensive growth in the New World can be viewed as bringing windfall gains that did much to explain the long period of increasing commercialization and Smithian growth which culminated in the Industrial Revolution. Over the long run, colonial trade not only enhanced the country's supply base but also changed the incentive structure in ways that stimulated efficiency improvements across the economy. ${ }^{57}$

New data collected by Klas Rönnbäck mostly support Williams' argument, as modified by Zahedieh, and strongly support an evolutionary argument for American and Caribbean plantation economies developing and strengthening over time. He has calculated the value added in the transnational value chains associated with the slave trade and the plantation complex. The slave trade was not a major contributor to British economic growth in the eighteenth century. Rönnbäck suggests that there was an annual real growth rate in the slave trade of $1.3 \%$ per annum, meaning that the value added through slave trading was comparatively small, and only increased marginally over time relative to British GDP. But, as Williams argued, wealth from the plantation complex generally conceived was extremely high, with sugar imports increasing tenfold over the eighteenth century and sustaining a $2.3 \%$ annual real growth rate. British exports to Africa and the

\footnotetext{
${ }^{53}$ Pierre Gervais, Yannick Lemarchand, and Dominique Margairaz, eds., Merchants and profit in the age of commerce, 1680-1830, London: Routledge, 2016.

${ }^{54}$ Nuala Zahedieh, 'Colonies, copper, and the market for inventive activity in England and Wales, 1680-1730', Economic History Review, 66, 3, 2013, pp. 805-25; Nuala Zahedieh. The capital and the colonies: London and the Atlantic economy, 1660-1700, Cambridge: Cambridge University Press, 2010, pp. 285 and 292.

${ }^{55}$ Pat Hudson, 'Slavery, the slave trade and economic growth: a contribution to the debate', in Hall et al., Emancipation, pp. 36-59.

${ }^{56}$ Ronald Findlay and Kevin H. O’Rourke, Power and plenty: trade, war, and the world economy in the second millennium, Princeton, NJ: Princeton University Press, 2009.

${ }^{57}$ Nuala Zahedieh, 'Regulation, rent-seeking, and the Glorious Revolution in the English Atlantic economy', Economic History Review, 63, 4, 2010, p. 887.
} 
Americas were similarly substantial in size, and similarly rapid in expansion over the eighteenth century. Rönnbäck concludes that plantation trade, including production on American plantations and industries dependent upon the American plantation complex, accounted for an annual value-added average of $3.5 \%$ of GDP in $1700-10$, rising to $11 \%$ of GDP in $1800-10 .^{58}$

In the remainder of this article we present three critiques of the NHC. First, we suggest that the traditional notion of 'merchant capitalism', with greater recognition of the close ties between it and early modern imperialism, is a better formulation than 'war capitalism': rather than emphasizing violence and coercion, we adopt an imperial and global approach that underlines the role played by European imperial powers in setting up and maintaining both slavery and the slave plantation system. Second, we consider issues of causality and argue that the emphasis given to cotton might suit an explanation centred on the role of the US South, but it was sugar that in the previous century shaped slavery. Finally, we point to the fact that the NHC highlights the role of labour at the expense of other factors, notably consumption. The picture changes substantially when consumers are reinserted into the narratives of capitalism and industrialization.

\section{'War capitalism' and the limitations of coercion}

Violence and the power of coercion are central to the NHC's explanation of how the slave economy worked, and in understanding slavery's contribution to global economic development. Yet the NHC fails to make a cogent case as to why the war capitalism of Atlantic slavery might be different from Afro-Eurasian slavery of previous centuries. The latter produced neither economic divergence nor industrialization. Capitalism - understood in its Weberian meaning of deployment of capital, search for profit, and market orientation - was supported by violence and coercion; yet more emphasis might be given to the ways in which the American plantation economy fitted within a wider geopolitical framework.

The casual substitution of 'war capitalism' by Beckert, and the assumption that 'various forms of interpersonal and state-sanctioned violence' underlined institutions that Rockman believes were less designed, in Douglass North's words, 'to create order and reduce uncertainty' than 'to exert and maintain power over the material world', are problematic, as much for Marxists as for neoclassical economists. ${ }^{59}$ As Robin Blackburn insists, violence was inseparable from the emergence of capitalism into the modern world' but 'to amalgamate all of these into "war" and elevate war into the "foundation" of industry is rhetoric, not historical argument". ${ }^{60}$

It was the exemplary efficiency of the British imperial state, not the brutality of war capitalism, that ensured a monopoly on colonial shipping, modulated the supply of colonial produce through bounties and excise duties, and made plantations part of an economic and political project that was not just domestic but also colonial in its ambitions. ${ }^{61}$ The key role of the colonial plantation system can be seen in the fact that the greatest part of the customs revenue of Britain in the eighteenth century came from the taxation of sugar, rice, and tobacco. ${ }^{62}$ Over the course of the eighteenth century, America became more important to the political economy of Britain than

\footnotetext{
${ }^{58} \mathrm{Klas}$ Rönnbäck, 'On the economic importance of the slave plantation complex to the British economy during the eighteenth century: a value-added approach', Journal of Global History, 13, 3, 2018, pp. 308-27. Data on imports from Elizabeth Boody Schumpeter, English overseas trade statistics, 1607-1808, Oxford: Clarendon Press, 1960, tables XVI and XVII.

${ }^{59}$ Comment by Seth Rockman in Andy Seal, 'Growth and price: Douglass North vs. the new history of capitalism', Society for US Intellectual History, https://s-usih.org/2019/03/growth-and-price-douglass-north-vs-the-new-history-of-capitalism/ (consulted 25 November 2019).

${ }^{60}$ Robin Blackburn, 'White gold, black bodies', New Left Review, 95, 2015, p. 160.

${ }^{61}$ Patrick K. O’Brien, 'Fiscal exceptionalism: Great Britain and its European rivals from Civil War to triumph at Trafalgar and Waterloo', in Donald Winch and Patrick K. O'Brien, eds., The political economy of British historical experience, 1688-1914, Oxford: Oxford University Press, 2002, pp. 245-65.

${ }^{62}$ Kenneth Morgan, 'Mercantilism and the British empire, 1688-1815', in Winch and O'Brien, Political economy, p. 174.
} 
was the case for other European states, such as France, Spain, and the Dutch Republic. ${ }^{63}$ Yet the political economy of the British state needs to be seen in a global context, one in which the interests of the East India Company and the revenue produced by trade to Asia were equally felt in Westminster, alongside slave-produced commodities from the Americas.

We also need to take into account the significant contributions made by Joseph Inikori, whose work on the role of Africans in the Atlantic world in industrialization over the longue durée has convinced some historians of British industrialization that the market-based model of industrialization cannot be successfully completed without an intensive involvement in international trade, particularly for a small country like England'. Inikori argues that the 'growth of England's international trade interacted with domestic factors - in particular population growth - to produce rapidly growing mass demand, which created opportunities and pressures that stimulated the development and diffusion of the new technologies of the Industrial Revolution'. ${ }^{64}$ His work helps to connect the demand side of the equation for explanations of the Industrial Revolution with supply-side factors, in ways that are more intellectually satisfying than the explanations proffered by the NHC for how slavery, capitalism, and industrialization were linked. ${ }^{65}$ Like Pomeranz, Inikori is interested in how a small country (England), with an initially narrow domestic market, could expand domestic production for export in consumer goods industries, doing so through tariff protection undertaken by the state. ${ }^{66} \mathrm{He}$ draws on Williams: as prime minister of Trinidad and Tobago, Williams was a strong advocate of dependency theory and of import substitution, and a great proponent in politics of the economic ideas of the West Indian economist Arthur Lewis. ${ }^{67}$

One problem with Inikori's (and Pomeranz's) analysis, a problem shared by all discussions of the role of international trade in the development of Britain's industrial economy, and the role of slavery in that development, is that most of the products that he argues were part of international trade came not from foreign countries but from within the empire. It is a mistake to see imports from the British West Indies and, before 1776, from British America as in any sense 'foreign', even though this is how they have always been described. ${ }^{68}$ White settlers in the American and Caribbean colonies of Britain did not see themselves as foreigners, but as proud Britons, as British as the residents of Sussex. That portions of Britain did not see American colonists as they saw themselves was a principal cause of the American Revolution. The more astute British economists recognized that the colonists in America were inseparable from Britons - they were merely Britons living overseas. Malachy Postlethwayt, for example, proclaimed that

since we have established colonies and plantations our condition ... has altered for the better ... our manufactures are prodigiously increased, chiefly by the demand for them in the plantations, where they at least take off one and a half and supply us with many valuable commodities for re-exportation, which is as great an emolument to the mother kingdom as to the plantations themselves. ${ }^{69}$

\footnotetext{
${ }^{63}$ William J. Ashworth, The Industrial Revolution: the state, knowledge and global trade, London: Bloomsbury, 2017, p. 117.

${ }^{64}$ Inikori, Africans and the Industrial Revolution, p. xv; 'Roundtable'.

${ }^{65}$ Inikori, Africans and the Industrial Revolution, p. 10.

${ }^{66}$ Relevant theoretical perspectives include H. J. Bruton, 'A reconsideration of import substitution', Journal of Economic Literature, 36, 1998, pp. 908-17; A. O. Hirschman, 'The political economy of import substituting industrialization in Latin America', Quarterly Journal of Economics, 82, 1968, pp. 1-32; Patrick K. O'Brien, Trevor Griffiths, and Philip Hunt, 'Political components of the Industrial Revolution: Parliament and the English cotton industry', Economic History Review, 44, 3, 1991, pp. 395-423; and Prasannan Parthasarathi, 'Rethinking wages and competitiveness in the eighteenth century: Britain and South India', Past \& Present, 158, 1990, pp. 79-109.

${ }^{67} \mathrm{~W}$. Arthur Lewis, The theory of economic growth, London: Allen and Unwin, 1955.

${ }^{68}$ Ralph Davis, 'English foreign trade, 1660-1700', Economic History Review, 7, 2, 1954, pp. 150-66; Ralph Davis, 'English foreign trade, 1700-1774', Economic History Review, 15, 2, 1962, pp. 285-303.

${ }^{69}$ Malachy Postlethwayt, Universal dictionary of trade and commerce, 2 vols., 4th edn, London, 1764.
} 
Eric Williams, unsurprisingly as the man who ushered Trinidad from being a colony to being independent, was well aware that the West Indies were not separate from Britain, and that enslaved Africans were not somehow outside imperial considerations. He quoted Postlethwayt most tellingly when describing the West Indies as the 'hub of the British Empire', noting that Postlethwayt considered 'Negro slaves' to be 'the fundamental prop and support' of British America within the British empire, 'a magnificent superstructure of American commerce and naval power upon an African foundation' ${ }^{70} \mathrm{NHC}$ accounts of capitalism and slavery fail to appreciate that the political nature of eighteenth-century imports of sugar and tobacco from colonies that were part of, rather than separate from, Britain is conceptually different from the importation of cotton from an independent US. Williams did not make this mistake. He made clear that his argument was a contribution by a resident of the British empire, even if temporarily in the US, and one with a complicated relationship to that institution, as well as to both British economic and British imperial history.

Slavery was not so indispensable to economic prosperity that it could not be dispensed with: that was Williams' point when he attributed the rise of anti-slavery to the West Indies suddenly becoming less important in imperial reckonings than it had been. We do not have to accept his argument that abolition arose out of metropolitan perceptions of West Indian economic decline. The evidence for such decline is not strong, given that Britain embarked on a great programme of imperial expansion of plantation agriculture in newly acquired Caribbean possessions from the 1790s. ${ }^{71}$ But what the abolitionist movement shows is that the British economy was sufficiently robust to withstand the ending of the slave trade without facing severe economic problems. Moreover, if Britain had not participated in the slave trade, the economic resources devoted to that industry would have been used in other productive industries. As with European powers without large American plantation possessions, the raw materials for Pomeranz's 'ghost acres' could have been imported from other parts of the world, without doing much damage to the British economy. ${ }^{72}$

What British West Indian planters had that other European planters did not have, at least until the start of abolition in the 1780s, was overwhelming support from the British state, and the benefits of imperial mercantilist policies. We can assess the importance of state support for plantation economies by comparing Britain with the Dutch Republic. In 1650, the Dutch share of world trade was larger than that of any other European nation. Its Atlantic possessions were impressive, including colonies based on slavery in Brazil, the Guianas, and to an extent North America, as well as a major slave-trading entrepôt in Elmina on the Gold Coast of West Africa. That Atlantic empire shrank after 1680, and the Dutch moved away from slave trading and large-scale plantations to becoming brokers and middlemen within a small empire, with extensive links to larger French, Spanish, Portuguese, and British Atlantic empires.

Dutch planters and slave traders, however, did not receive the extensive protection from their state that their counterparts in Britain did. The Dutch competed against increasingly cost-effective sugar producers, notably the French in Saint-Domingue, resulting in relatively low profits in the slave trade and in Dutch West Indian plantation agriculture. The protective tariffs in place in the British empire for plantation produce were highly beneficial to British American planters, allowing them to enjoy comparatively high incomes from inflated prices for their produce in the British

\footnotetext{
${ }^{70}$ Malachy Postlethwayt, The African trade, the great pillar and support of the British plantation trade in North America, London, 1745, pp. 4 and 6; Williams, Capitalism and slavery, p. 52.

${ }^{71}$ Christer Petley, 'Slaveholders and revolution: the Jamaican planter class, British imperial politics, and the ending of the slave trade, 1775-1807', Slavery \& Abolition, 39, 1, 2018, pp. 53-79.

${ }^{72}$ Rönnbäck, 'Economic importance', pp. 312-13; Gregory Clark et al., 'Made in America? The New World, the old, and the Industrial Revolution', American Economic Review, 98, 2008, pp. 523-28; Karwan Fatah-Black and M. R. Van Rossum, 'Beyond profitability: the Dutch transatlantic slave trade and its economic impact', Slavery \& Abolition, 36, 1, 2015, pp. 63-83; David Eltis, Pieter C. Emmer, and Frank D. Lewis, 'More than profits? The contribution of the slave trade to the Dutch economy: assessing Fatah-Black and Van Rossum', Slavery \& Abolition, 37, 4, 2016, pp. 724-35.
} 
market, and extra demand from high-wage-earning consumers buying sugar and other products at lower than normal prices. The British consumer could buy more sugar than any other European, while paying less for it. The result was great wealth for American and West Indian planters. That wealth was accentuated by rapid population growth through natural increase and immigration in the northern colonies of British North America. ${ }^{73}$

\section{The chronology of slavery and cotton}

The peak of planter political power came in the early and mid eighteenth century, and not in the late eighteenth or nineteenth centuries. State support for planters, the plantation complex, slavery, and the slave trade in Britain and British America was far from constant. There was just one period, from the Glorious Revolution in 1688 until the end of the Seven Years' War in 1763, in which Britain supported the planters' interests almost without reservation. Planters enjoyed healthy profits, an increasingly effective and efficient slave trade, favourable imperial legislation, highly advantageous economic privileges, and minimal public opposition to slavery. ${ }^{74}$ Especially in the period between the Treaty of Utrecht in 1714 and the Peace of Paris in 1763, slave colonies in the West Indies and British North America were nurtured within an empire that gave them ample support through generous land grants, state-sponsored negotiations with Native Americans that provided temporary peace, massive incentives for private trading in the slave trade, and protected markets for products grown by slaves. ${ }^{75}$

We do not see the Industrial Revolution and global divergence in 'big bang' terms. ${ }^{76}$ The former, we argue, proceeded over at least a century, and the latter developed over several centuries. ${ }^{77}$ Examining the links between slavery and industrialization shows why taking the long view is preferable to accounts emphasizing sudden disruption to economic growth through somewhat mysterious alterations in either the national or the global economy. We prefer to see Europe's comparative advantage after 1800 coming from the continent's changing interaction with other parts of the world starting in the sixteenth century, and involving the learning of technologies, new products and raw materials, and cultural and social changes at home, which allowed for products, technologies, and resources to be integrated into the socioeconomic system of the West. ${ }^{78}$ Slavery fits best into a schema of 'layering' of causes, rather than one based on mono-causal factors leading to great economic leaps. Julian Hoppit argues that, in a relatively complex economy such as Britain's in the eighteenth century, multi-causality and complex interrelations operated, such that any one major factor sat alongside many others and yet was a requirement for the whole to operate as well as it did'. ${ }^{79}$

Both Williams and Beckert believe that the British development of slavery preceded the 'big bang' of industrialization. We argue conversely that slavery and industrialization were new economic forms of organization that developed in Britain and its empire at roughly the same time.

\footnotetext{
${ }^{73}$ Stanley Engerman, 'British imperialism in a mercantilist age, 1492-1849: conceptual issues and empirical problems', Revista de Historia Económica, 16, 1998, pp. 206-8.

${ }^{74}$ Lorena S. Walsh, Motives of honor, pleasure, and profit: plantation management in the colonial Chesapeake, 1607-1763, Chapel Hill, NC: University of North Carolina Press, 2010; Trevor Burnard, Planters, merchants, and slaves: plantation societies in British America, 1650-1820, Chicago, IL: University of Chicago Press, 2015.

${ }^{75}$ Steve Pincus, The global British empire, ca. 1650-1784, New Haven, CT: Yale University Press, forthcoming; C. Knick Harley, 'Slavery, the British Atlantic economy and the Industrial Revolution', University of Oxford Discussion Papers in Economic and Social History 113, April 2013, https://www.economics.ox.ac.uk/materials/papers/12739/harley113.pdf (consulted 25 November 2019).

${ }^{76}$ Robert C. Allen, The British Industrial Revolution in global perspective, Cambridge: Cambridge University Press, 2009.

${ }^{77}$ Joel Mokyr, 'Peer Vries's Great Divergence', TSEG/Low Countries Journal of Social and Economic History 1, 2015, pp. 93-104.

${ }^{78}$ Giorgio Riello, Cotton: the fabric that made the modern world, Cambridge: Cambridge University Press, 2013, pp. 9-10.

${ }^{79}$ Julian Hoppit, Britain's political economies: Parliament and economic life, 1660-1800, Cambridge: Cambridge University Press, 2017, p. 322.
} 
They generally reinforced, though sometimes contradicted, each other. It was easy for British governments to support both slavery and early industrialization because they largely complemented one another, and increased Britain's national prosperity.

Timing is also relevant when looking at the role played by cotton in early industrialization. For Beckert, slavery and cotton are inseparable. He correctly argues that market-aware planters moved into cotton production as soon as they realized that the enormous demand for cotton in the early Industrial Revolution would make them substantial profits. But American cotton was not the impetus behind British industrialism, an idea that is based on the assumption that vast quantities of cheap raw materials spurred a creative technological effort towards mechanization. A great deal has been made of Eli Whitney's cotton gin, which was first introduced in Georgia in 1793; but the American South became a major world cotton producer only in the 1810 s, and retained such a position for just over a generation. Moreover, the substitution of cotton for other tropical commodities only happened well into the nineteenth century. When raw cotton first became important for the burgeoning British textile industry in the $1780 \mathrm{~s}$, it was imported into Europe from the West Indies, and was produced without the benefits of Whitney's cotton gin..$^{80}$ Cotton was of marginal importance until the second half of the eighteenth century, and only became significant during the first decade of the nineteenth century, when a rapid increase led to cotton accounting for $£ 1$ million in trade, outstripping in importance tobacco, though not sugar, among tropical commodities. ${ }^{81}$

Beckert's idea - that supplies of cotton from America show that slave plantations were indispensable for the development of mechanized cotton textile production - is implausible, because it is relatively easy to compose counterfactual alternatives to American cotton, in which producers in Asia and the Middle East responded to European demand for cotton fibres by changing production towards cotton. ${ }^{82}$ India, in particular, had major advantages over America in the notional supply of cotton to Britain, because it had grown cotton for centuries. It was adept at cotton technology, and in providing the cotton manufactures that Britain and Europe desired. Its replacement as the main provider of cotton cloth to Britain came from a failure on the part of Indian manufacturers to keep up with the changing patterns of European taste for printed cottons. ${ }^{83}$

A counterfactual technique is useful for imagining an industrial revolution that was based on either woollen textiles or on linen, in which the 'ghost acres' celebrated by Pomeranz could have been devoted to sheep production in Australia or to flax in Russia - countries with more free land than the United States. ${ }^{84}$ If Britain had colonized Australia in 1688, one can easily imagine that a country with a long tradition in wool production would have used wool from vast flocks of Australian sheep to kick-start the industrial production of woollen textiles. ${ }^{85}$ Indeed, the story of Australian wool is not even a counterfactual. After production started in earnest in the first decades of the nineteenth century, Australia became a reservoir of wool for a buoyant Victorian woollen industry. ${ }^{86}$

Early industrialists therefore did not have to choose cotton as the instrument of industrialization over other plausible commodities. Australian wool and Russian linen were plausible alternatives to slave-produced cotton as stimuli to industrialization. ${ }^{87}$ That Britain chose to specialize in

\footnotetext{
${ }^{80}$ Beckert, Empire of cotton, pp. 88-93; Riello, Cotton, pp. 194-203.

${ }^{81}$ Rönnbäck, 'Economic importance', p. 319.

${ }^{82}$ Beckert, Empire of cotton.

${ }^{83}$ Giorgio Riello and Prasannan Parthasarathi, eds., The spinning world: a global history of cotton textiles, 1200-1850, Oxford: Oxford University Press, 2009.

${ }^{84}$ Giorgio Riello, 'Counting sheep: a global perspective on wool, 1800-2000', in Giovanni Luigi Fontana and Gérard Gayot, eds., Wool: products and markets, 13th-20th century, Padua: CLEUP, 2004, pp. 103-31; Riello, Cotton, ch. 11.

${ }^{85}$ Stephen H. Roberts, History of Australian land settlement, 1788-1920, London: Frank Cass, 1969, pp. 163-5.

${ }^{86} \mathrm{Pat}$ Hudson, 'The limits of wool and the potential of cotton in the eighteenth and early nineteenth centuries', in Riello and Parthasarathi, Spinning world, pp. 327-50.

${ }^{87}$ Riello, 'Counting sheep'.
} 
cotton, rather than wool, with which it was intimately familiar and had been familiar for many centuries, is surprising, given how little knowledge Britons had about cotton's cultivation, processing, and consumption. In 1751, a committee of the House of Commons dismissed cotton as 'only a temporary thing', a cheap substitute for expensive flax, and an alternative to wool, which in the 1760 s was not produced in the quantities needed for clothing a growing population. ${ }^{88}$ American cotton could have been excluded from Britain, as retaliation for the breakaway of the Thirteen Colonies. The invention of the cotton gin could have come later than 1793, thus allowing other countries, and possibly other fibres, to take the place of American cotton. A concerted campaign by consumers targeting cotton products could have developed, emulating the campaign against slave-grown sugar, which had major success in altering consumption habits, and which struck a particular chord among abolitionist women. ${ }^{89}$

In addition, cotton need not have been produced by slaves. For millennia, in India and China, cotton was produced by women in peasant households in forms of household production..$^{90}$ Once the American Civil War ended, cotton was produced by small yeomen farmers in late nineteenth-century upcountry Georgia. ${ }^{91}$ If slavery and cotton went together, they did so for not much more than a century. They only look inseparable from the perspective of the slaveholding and cotton-producing nineteenth-century American South. ${ }^{92}$

\section{The power of consumption}

The NHC concentrates on cotton as the main crop inducing industrial development, but the major tropical crop in the eighteenth-century transatlantic trade was sugar. In contrast to cotton, sugar facilitated the growth of a consumer culture. It played a vital role among several 'luxury' products in altering the fabric of everyday British life. And it played a key role in elaborate cultural moments, such as teatime for the rising British middle classes. The 'consumer revolution' of the early eighteenth century relied to a surprising degree upon the goods produced by slaves, sugar being the most important. ${ }^{93}$

Moreover, the people who grew rich from sugar seldom put their profits into Lancashire cotton mills. More commonly, they engaged in gentry consumption, including fancy houses, expensive forays into parliamentary politics, and lavish displays of often questionable taste. ${ }^{94}$ As Richard Pares acidly noted, 'there seem to have been more Fonthills than factories among them, and more overdrafts and protested bills than either. ${ }^{95}$ Slavery was therefore relatively unimportant in financing industrialization, even while it added to the sum of economic activities in

\footnotetext{
${ }^{88}$ House of Commons report cited in Beverley Lemire, 'Transforming consumer custom: linen, cotton, and the English market, 1600-1800', in Brenda Collins and Phillip Ollerenshaw, eds., The European linen industry in historical perspective, Oxford: Oxford University Press, 2003, p. 198; Philip McMichael, Settlers and the agrarian question: foundations of capitalism in colonial Australia, Cambridge: Cambridge University Press, 1984, pp. 146-8; Pat Hudson, The genesis of industrial capital: a study of the West Riding wool textile industry, c. 1750-1850, Cambridge: Cambridge University Press, 1986.

${ }^{89}$ Julie L. Holcomb, 'Blood-stained sugar: gender, commerce and the British slave-trade debates', Slavery \& Abolition, 35, 4, 2014, pp. 611-28.

${ }^{90}$ Sanjay Subrahmanyam, The political economy of commerce: southern India, 1500-1650, Cambridge: Cambridge University Press, 2002; Prasannan Parthasarathi, The transition to a colonial economy: weavers, merchants and kings in south India, 1720-1800, Cambridge: Cambridge University Press, 2001.

${ }^{91}$ David Weiman, 'The economic emancipation of the non-slaveholding class: upcountry farmers in the Georgia cotton economy', Journal of Economic History, 45, 1, 1985, pp. 71-93.

${ }^{92}$ Ralph V. Anderson and Robert E. Gallman, 'Slaves as fixed capital: slave labor and Southern economic development', Journal of American History, 64, 1, 1977, pp. 24-46.

${ }^{93}$ Woodruff D. Smith, Consumption and the making of respectability, 1660-1800, New York and London: Routledge, 2002.

${ }^{94}$ Smith, Slavery, family and gentry capitalism; James Walvin, Sugar: the world corrupted, from slavery to obesity, London: Robinson, 2017; Sidney W. Mintz, Sweetness and power: the place of sugar in modern history, New York: Penguin, 1985.

${ }^{95}$ Fonthill was the home of the wealthy Beckford planter family. Richard Pares, 'The economic factors in the history of the empire', Economic History Review, 7, 2, 1936-7, p. 130.
} 
eighteenth-century Britain, of which industrialization was only a small part. In Patrick O'Brien's words, 'for the economic growth of the core, the periphery was peripheral'. ${ }^{96}$ Indeed, occasionally people whom one might have thought likely to have provided capital to fund factories, such as the Liverpool merchant John Gladstone, decided that slavery was a better investment, even after the Industrial Revolution was well underway, than cotton textile production. ${ }^{97}$

Where slavery was important was in stimulating demand for manufactures. Jan de Vries and Maxine Berg explain that early eighteenth-century Britain was unusually receptive to buying luxury groceries - notably sugar - produced in the Americas; to purchasing printed cotton goods from India; and to craving the industrial products that emerged out of early manufacturing efforts. Some of these efforts developed out of the technological improvements that allowed British manufacturers to compete with India in cottons. ${ }^{98}$ Because Britain in the early eighteenth century had a robust consumer base, owing to the prior capitalist transformation of the countryside, an Industrial Revolution was possible. This capitalist transformation of the English countryside thus preceded global economic integration and was necessary both for slavery as it developed in British America and for the Industrial Revolution. ${ }^{99}$

Whether a consumer revolution was a precondition for an industrial one is debatable. A focus on consumption, however, allows us to question the prominence given to modes of production in the NHC. In fact, one can make the opposite causal claim, when observing that the craving for New World commodities, such as sugar, cocoa, and eventually cotton, came to shape labour and production not just in the Americas but also in Europe. De Vries, in his concept of an industrious revolution, sees tropical produce and Asian-manufactured commodities as central to a European shift from household to market-driven production, with a need to secure cash to buy imported commodities. ${ }^{100}$ What is central in this argument is the change of labour patterns in England, where new commodities (some of which were produced by slaves) led to an intensification of labour. The opposition between free (peasant and industrial) and unfree (slave but also indentured) labour is being revised at present, by underlining the global connections of labour markets, and their relationship not just to specific forms of organization of production, but also to forms of consumption. ${ }^{101}$

One advantage of looking closely at consumption patterns is that we can move away from concentrating on production and the role of men - merchants, planters, and politicians - towards examining both men and women, and the choices they made about the goods they bought. Female European consumers played a leading role in fashioning demand for cotton products, and for determining how those products should look and feel. Indeed, the reason that Indian cottons in Europe and Africa initially succeeded, and then were replaced by European-produced goods, was the strong preference that European women had for certain types of cloths that Indian suppliers proved reluctant or unable to provide. ${ }^{102}$ It was not just the increased easing of the

\footnotetext{
${ }^{96}$ Patrick K. O'Brien, 'European economic development: the contribution of the periphery', Economic History Review, 35, 1, 1982, p. 18; R. C. Nash, 'The balance of payments and foreign capital flows in eighteenth-century England: a comment', Economic History Review, 50, 1, 1997, pp. 110-28.

${ }^{97}$ S. G. Checkland, 'Finance for the West Indies, 1780-1815', Economic History Review, 10, 2, 1958, pp. 461-69.

${ }^{98} \mathrm{Jan}$ de Vries, The industrious revolution: consumer behavior and the household economy, 1650 to the present, New York: Cambridge University Press, 2008.

${ }^{99}$ Robert C. Allen, 'Agriculture during the Industrial Revolution, 1700-1850', in Roderick Floud and Paul Johnson, eds., The Cambridge economic history of modern Britain 1700-1860, Cambridge: Cambridge University Press, 2004, pp. 96-116.

${ }^{100}$ De Vries, Industrious revolution; Jan de Vries, 'The limits of globalization in the early modern world', Economic History Review, 63, 3, 2010, pp. 710-33.

${ }^{101}$ Alessandro Stanziani, 'Labour regimes and labour mobility from the seventeenth to the nineteenth century', in Tirthankar Roy and Giorgio Riello, eds., Global economic history, London: Bloomsbury, 2018, pp. 175-94.

${ }^{102}$ Giorgio Riello, 'The globalization of cotton textiles: Indian cottons, Europe and the Atlantic world, 1600-1850', in Riello and Parthasarathi, Spinning world, pp. 261-87; John Styles, 'What were cottons for in the Industrial Revolution?', in ibid., pp. 307-26; John Styles, 'Indian cottons and European fashion, 1400-1800', in Glenn Adamson, Giorgio Riello, and Sarah Teasley, eds., Global design history, London: Routledge, 2011, pp. 37-45.
} 
supply of cotton from America after 1794 which shaped changing global patterns of production. Changes in supply reflected changes in demand. The integration of markets in the nineteenth century brought about a visual and aesthetic convergence of taste that favoured European manufactured goods. As Europeans proved more adept than Indians in producing fabrics that appealed to female tastes in Europe and Africa, European manufacturing prospered, while Indian manufacturing declined. ${ }^{103}$

Slavery is thus part of a narrative of substitution of Indian cotton textiles by mixes of linens and cottons and by pure cotton cloth produced in the British Isles and continental Europe. Central to this story of substitution, and to the demand for raw cotton supplies from the Americas, was consumer demand for a variety of cloths - plain, printed, and chequered - that complemented imports from India by the English and other European companies. ${ }^{104}$ Without considering consumer demand for finished products, it is impossible to understand the dynamics of any raw material market, including cotton and sugar. These products came to reshape consumer patterns in the West, providing new leisure activities for the middle classes, and cheap calorific intake for the working classes. ${ }^{105}$

The eighteenth-century story of the British economy is thus not a straightforward account of import-substitution industrialization: that is, of infant industries developed behind high tariff walls to supply domestic markets. Instead, Europeans responded to imports from other parts of Europe, but especially from Asia (only partially under European control), by learning from the things that they imported, developing knowledge of models and adapting processes. ${ }^{106}$ Inikori shows that similar challenges and opportunities for Europeans to learn from Africans came from products from Africa, notably Senegal gum from acacia trees, which was vital for the development of European paper-making and textile-printing. ${ }^{107}$

Slaves were also consumers, notably of cloth. By the 1770 s, 600,000 enslaved Africans, together with more than two million white colonists and 600,000-800,000 Native Americans, formed an important market for the very commodities that were cultivated in British America. Throughout the eighteenth century, British American colonies were a dynamic market for British manufacturers. Britain's exports to the West Indies and North America increased from a respectable $11 \%$ of all overseas trade in 1700 to an impressive $56 \%$ by 1800 . American markets in the plantation regions purchased goods worth around $£ 1.8$ million in 1800 , an average growth rate over the eighteenth century of $2 \%$ per annum. ${ }^{108}$

The timing of this growth in Atlantic trade occurred after the initial push to industrialization. Early mechanization in Britain, alongside a protective wall for the benefit of British American planters, allowed Britain's innovative merchants to offer an impressive and growing array of consumer goods to British settlers. These settlers had strong purchasing power, thanks to imperial

\footnotetext{
${ }^{103}$ Riello, Cotton, pp. 265-9, 278-82.

${ }^{104}$ Beverly Lemire, Cotton, Oxford: Berg, 2011, pp. 33-64; Robert S. DuPlessis, 'Cloth and the emergence of the Atlantic economy', in Peter A. Coclanis, ed., The Atlantic economy during the seventeenth and eighteenth centuries: organization, operation, practice, and personnel, Columbia, SC: University of South Carolina Press, 2005, pp. 73-94; Robert S. DuPlessis, 'Cottons consumption in the seventeenth- and eighteenth-century north Atlantic', in Riello and Parthasarathi, Spinning world, pp. 227-46; Robert DuPlessis, The material Atlantic: clothing, commerce, and colonization in the Atlantic world, 1650-1800, Cambridge: Cambridge University Press, 2015.

${ }^{105}$ Christine Fertig and Ulrich Pfister, 'Coffee, mind and body: global material culture and the eighteenth-century Hamburg import trade', in Anne Gerritsen and Giorgio Riello, eds., The global lives of things: the material culture of connections in the early modern world, Basingstoke: London, 2016, pp. 221-40; Maxine Berg, 'Consumption in global history in the early modern period', in Roy and Riello, Global economic history, pp. 118-33.

${ }^{106}$ Maxine Berg, 'In pursuit of luxury: global history and British consumer goods in the eighteenth century', Past \& Present, 182, 2004, pp. 85-142.

${ }^{107}$ Inikori, Africans and the Industrial Revolution, pp. 381-404. See also Philip D. Curtin, Economic change in pre-colonial Africa: Senegambia in the era of the slave trade, Madison, WI: University of Wisconsin Press, 1975.

${ }^{108}$ Kenneth Morgan, Slavery, Atlantic trade and the British economy, 1600-1800, Cambridge: Cambridge University Press, 2009, p. 19; Rönnbäck, 'Economic importance', fig. 5.
} 
preferences that gave them privileged access to a highly desirable British market, full of highwage-earning consumers eager to incorporate plantation products such as sugar into evolving cultural practices like the afternoon tea ceremony. ${ }^{109}$ In short, the industrious revolution and then the Industrial Revolution stimulated the development of Atlantic economies, including those based on plantation slavery, rather than the other way around. ${ }^{110}$ This stimulation occurred before the American Revolution. But the quality and cheapness of British manufactured goods was so great, compared to Dutch and French manufactured goods, that British manufactures remained in demand in the United States of America, even after imperial protection for colonial markets was removed. ${ }^{111}$

\section{Conclusion}

Slavery was not unimportant in fashioning economic change in the vital early period of industrialization. However, this statement needs some qualifications. The Williams thesis, that the reinvested profits of slave trading and slave ownership were extremely important in early industrialization, remains overstated. Slavery did not cause the Industrial Revolution. Indeed, Williams himself never made such a sweeping claim, as proponents of the NHC do not fully recognize. ${ }^{12}$ But, as Solow argued, and as Gareth Austin has reiterated, colonial trade made 'an important, perhaps even necessary, contribution to the British origins of global industrialization'. ${ }^{113}$ In other words, slavery had an influence on the pattern and timing of how industrialization unfolded. In this respect, the arguments put forward by the NHC are accurate.

Nevertheless, some of the specific claims made by the NHC need to be modified. Going in inverse order: if, as the NHC argues, slavery and slave plantations are central to the shaping of a 'modern' capitalist system, so must be the commodities that were produced in plantations by enslaved labour. By focusing solely on labour regimes, the NHC has proposed a skewed interpretation, which ignores the connection between labour, manufacturing, and consumption. Sugar and cotton are therefore the keys to a story of capitalist transformation that is not just about power and exploitation, but also about the shaping of global markets. ${ }^{114}$ Britain worked hard to establish a leading position in the world as a cotton manufacturer. It produced goods that consumers wanted, not just in Britain, but also in Africa (to pay for slaves) and in the American colonies (soaking up money that came in large degree from direct and indirect profits from slavery). Over the long run, British manufacturers succeeded in producing goods that consumers were willing to buy. Thanks to low prices and enormous amounts of merchandise, British and eventually other European manufacturers created a demand for their manufactures that other producers, notably in India, could not match. ${ }^{115}$

Second, by emphasizing the role of cotton cultivation in the antebellum United States, the chronologies developed by the NHC are problematic. It was in the first half of the eighteenth century that the political economy of slavery was most important, not in the second half of that century, or

\footnotetext{
${ }^{109}$ Woodruff D. Smith, 'Complications of the commonplace: tea, sugar, and imperialism', Journal of Interdisciplinary History, 23, 2, 1992, pp. 259-78.

${ }^{110}$ C. Knick Harley, 'Slavery, the British Atlantic economy, and the Industrial Revolution', in A. B. Leonard and David Pretel, eds., The Caribbean and the Atlantic world economy: circuits of trade, money and knowledge, 1650-1914, Basingstoke: Palgrave Macmillan, 2015, p. 182.

${ }^{111}$ Riello, Cotton, p. 66.

${ }^{112}$ For overstatements of Williams' claims, see Seth Rockman's comment that Williams 'postulated that West Indian slavery financed English industrialization': Rockman, 'The unfree origins of American capitalism', in Cathy Matson, ed., The economy of early America, University Park, PA: Pennsylvania State University Press, 2006, p. 347.

${ }^{113}$ Gareth Austin, 'Capitalism and the colonies', in Neal and Williamson, Cambridge history of capitalism, vol. 2, p. 310.

${ }^{114}$ Roy and Riello, Global economic history, part 2.

${ }^{115}$ DuPlessis, Material Atlantic, pp. 4, 7-8.
} 
in the nineteenth century, as the NHC argues. The NHC overstates the importance of slavery to the Industrial Revolution, and obscures important contributions made by slavery that shaped British, and more generally European, economic growth in the seventeenth and eighteenth centuries. These were separate from the traditional tale of a sudden explosion in industrial activity in the second half of the eighteenth century.

Third, it was not simply the case that, unlike Qing China, Britain had access to plantations and colonial markets. Other European empires had large markets of consumers in their American possessions. Britain 'capitalized' most on its empire, thanks to a specific political economic vision that combined slavery, plantations, consumption, and taxation, as Williams posited. Its high-wage economy and demanding consumers provided an incentive to early industrialists to concentrate heavily on the demand side of the demand-supply equation. High rates of urbanization in Britain and its wealthy colonies, with city dwellers eager to buy British goods, only accentuated British advantages. ${ }^{116}$

In conclusion, in discussing slavery's contribution to economic growth in eighteenth-century European empires, we need to return to the global. If we accept the NHC's totalizing tendency, the Americas, later narrowed to the United States, become the new core in a Wallersteinian narrative. This narrative is to the detriment of explanations that have emphasized a multiplicity of factors in the connections between capitalism and slavery; that have adopted comparative methodologies (between Europe and China, or Europe and India); and that have provided much thought on the economic mechanisms at play, beyond the commonplace view that the violence of thugs always wins. Thugs may win a great deal, but they win only when the structures that maintain their power make their thuggery viable. ${ }^{117}$

Trevor Burnard is Wilberforce Professor of Slavery and Emancipation and the Director of the Wilberforce Institute at the University of Hull. He is the author of Jamaica in the age of revolution (2020), The Atlantic in world history, 1492-1830 (2000), and Britain and the wider world, 1603-1800 (2020). He is editor-in-chief of the Oxford bibliographies online in Atlantic history.

Giorgio Riello is Chair of Early Modern Global History at the European University Institute in Florence. He is the author of Cotton: the fabrics that made the modern world (2013), Luxury: a rich history (2016, co-authored with Peter McNeil), and Back in fashion: Western fashion from the Middle Ages to the present (2020).

\footnotetext{
${ }^{116}$ Allen, British Industrial Revolution, pp. 106-32.

${ }^{117}$ Peer Vries, Escaping poverty: the origins of modern economic growth, Vienna: Vienna University Press, 2013; Joel Mokyr, A culture of growth: origins of the modern economy, Princeton, NJ: Princeton University Press, 2016.
}

Cite this article: Burnard T., and Riello G. 2020. Slavery and the new history of capitalism. Journal of Global History 15: 225-244, doi:10.1017/S1740022820000029 